
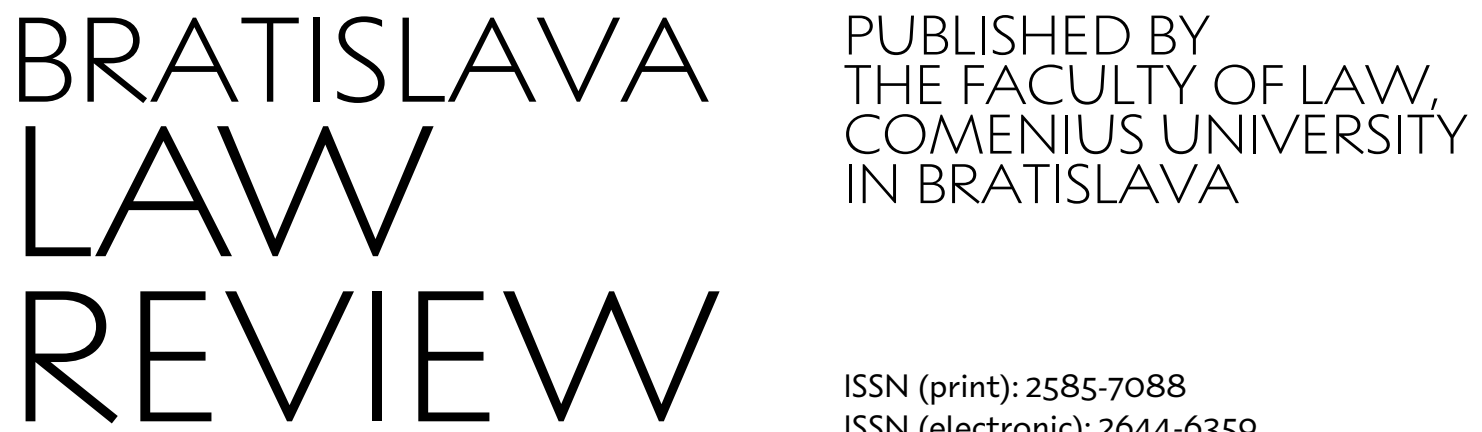

ISSN (print): $2585-7088$

ISSN (electronic): 2644-6359

\title{
CIVIL LAW ASPECTS OF THE MAURITIAN CHILDREN'S BILL OF 2019 / Goran Georgijević
}

\author{
Goran Georgijević, PhD:; \\ Faculty of Law and Management \\ University of Mauritius, FLM Building, \\ Réduit, Mauritius; \\ g.georgijevic@uom.ac.mu; \\ ORCID: 0000-0002-9734-1324
}

Submitted: 4 May 2020 Accepted: 28 June 2020 Published: 31 August 2020

\begin{abstract}
The Mauritian Children's Bill of 2019 addresses many issues pertaining to child protection, such as best interest of a child, prohibition of discrimination of children, marriage of children, ill-treatment of children, surrogacy and sale of children and child prostitution. However, we may observe that the Bill regulates mainly the criminal law aspects as well as the administrative measures aiming at protecting children. The Bill does not contain the rules on Civil law aspects of the issues addressed in the Bill. In this article, we will analyse those Civil law aspects.
\end{abstract}

Key words: child protection; children's rights; the best interest of a child principle; civil law; comparative view; Mauritian law; French law

\section{Suggested citation:}

Georgijević, G. (2020). Civil Law Aspects of the Mauritian Children's Bill of 2019. Bratislava Law Review, 4(1), 143-166. https://doi.org/10.46282/blr.2020.4.1.178

\section{INTRODUCTION}

The Mauritian Children's Bill of $2019^{1}$ is intended, as per the Explanatory Memorandum attached to the Bill, "to repeal the Child Protection Act and replace it with a more appropriate, comprehensive and modern legislative framework so as to better protect children and to give better effect to the United Nations Convention on the Rights of the Child and the African Charter on the Rights and Welfare of the Child". ${ }^{2}$ The objectives of the above mentioned Bill are numerous and various. Many of them pertain to criminal law issues or to administrative measures for protection of children, but none of them

\footnotetext{
${ }^{1}$ It has to be noted that according to Section 2 of the Bill, a child is defined as "a person under the age of 18 ". Section 2 is in conformity with Article 388 of the Mauritian Civil Code that defines a minor as "an individual of each sex who is under the age of 18 ".

${ }^{2}$ According to paragraph 2 of the above mentioned Explanatory Memorandum, the Bill "makes provisions -

(a) for the better care, protection and assistance to children and their families;

(b) for the respect and the promotion of the rights and best interests of children;

(c) for the setting up of structures, services and means for promoting and monitoring the sound physical, psychological, intellectual, emotional and social development of children;

(d) for children under the age of 12 not to be held criminally responsible for any act or omission;

(e) for child witness and child victims under the age of 14 to be, under certain conditions, competent as witnesses without the need for them to take the oath or making solemn affirmation;

(f) for the setting up of a Children's Court, which shall consist of a Civil Division, a Protection Division and a Criminal Division; and

(g) for addressing the shortcomings in the Child Protection Act.".
} 
concerns directly Mauritian Civil Law. In this article, we will attempt to analyse in detail Civil law aspects of the Mauritian Children's Bill of 2019 and its relationship with the Civil law legislation.

The Mauritian legal system is very often described as the hybrid or the mixed one. One part of it, more precisely the Public Law (Constitutional Law, Administrative Law, etc.), is of Common Law inspiration. On the other hand, and for historical reasons, Mauritian civil law has been influenced by French civil law (Agostini, 1992, p. 21; Angelo, 1970, p. 237; Bogdan, 1989, p. 28; Domingue, 2002, p. 62; Law Reform Commission, n.d.; Valentine, 2012, p. 629; Venchard, 1982, p. 31). The French Civil Code, which came into force in 1804, has influenced the Civil Code of the Republic of Mauritius. The original text of the French Civil Code of 1804 was incorporated into the positive law of Mauritius. This is due to the fact that at the early $19^{\text {th }}$ century, Mauritius was a French colony, before the English took possession of the Island. Article 8 of the Act of Surrender, signed in 1810, provided that the People of the Island would maintain their religion, laws and customs. In addition, the Treaty of Paris of 1814, which officially transfers the legal possession of Mauritius to the Englishmen, does not have the effect of fundamentally overturning French laws considered in certain respects as the personal legislation of the inhabitants (Venchard, 1982, p. 31). Consequently, Mauritian civil law and, in particular, the Mauritian Civil Code, was modelled on French civil law and the French Civil Code of the time.

Despite the great resemblance between Mauritian civil law and French civil law, the former has managed to preserve an indisputable autonomy vis-à-vis the latter. In Mauritius, the decisions of the French Court of Cassation are a persuasive and not a binding authority on Civil law issues. ${ }^{3}$ Thus, a Mauritian judge will quote and follow the reasoning developed in a judgment of the French Court of Cassation only if the judge considers it appropriate with respect to the context. On the other hand, no formal obligation lies upon the Mauritian judge to follow the decisions of the Court of Cassation relating the issue treated in the judgment. This rule has been, for instance, clearly confirmed with regard to the issue of reparation for indirect damage suffered by an unmarried partner in the event of the death of the other partner. The Supreme Court of Mauritius refuses constantly the reparation for indirect damage, moral or material, suffered by an unmarried partner in the event of the death of the other partner. This position is clearly expressed in the Mauritian Supreme Court's judgments Jugessur Mrs Shati \& ORS v. Bestel Joseph Christian Yann \& Anor $\left(26^{\text {th }}\right.$ April 2007) ${ }^{4}$ and Naikoo v. Société Héritiers Bhogun (Record number 14 949). ${ }^{5}$ Three main arguments are given in order to justify the above mentioned refusal, i.e. the immorality of the union of unmarried partners, the absence of legal link between unmarried partners as well as the existence of some kind of "legal fault" which consists in living together without being married. On the other hand, since 1970 the French Court of Cassation has been acknowledging the reparation for indirect damage suffered by an unmarried partner in the event of the death of the other partner. According to the French Court of Cassation, the union between two unmarried persons is not illegal and the lack of legal link between unmarried partners

\footnotetext{
${ }^{3}$ In the judgement of the Supreme Court of Mauritius Lingel-Roy M. J. E. M. and ORS v. The State of Mauritius and Anor 2017 SCJ 411 we can read: "It is appropriate to recall the practice that when it comes to the interpretation of a law borrowed from French law we stand guided for its interpretation by French doctrine and case law. One can quote in that respect the following passage from L'Etendry v The Queen [1953 MR 15]: "the normal rule of construction laid down time and again by this court (...) is to the effect that when our law is borrowed from French law we should resort for guidance as to its interpretation to French doctrine and case law." But, it has to be pointed out that the practice of relying on French authorities has always been for guidance and not in application of the stare decisis principle."(highlighted by author)

42007 SCJ 106.

51972 MR 661972.
} 
does not constitute an obstacle to the reparation for indirect damage. ${ }^{6}$ However, despite all the differences between Mauritian civil law and French civil law which have been pointed out previously and despite the indisputable autonomy of the Mauritian civil law, it is impossible to deny that the latter is strongly inspired by French civil law and that the Mauritian judge will refer most of the time to the decisions rendered by French courts and especially by the Court of Cassation - as well as to the French doctrine.

This is why we will constantly refer to the French Doctrine as well as the judgments of the French Court of Cassation while analysing the Civil law aspects of the Mauritian Children's Bill of 2019.

\section{RELATION BETWEEN THE CHILDREN'S BILL AND THE MAURITIAN CIVIL CODE}

\subsection{The Coexistence between the Children's Bill and the Mauritian Civil Code}

Section 3 (2) of the Mauritian Children's Bill of 2019 clearly states the relationship between the Bill and Articles 371 through 387 of the Code Civil Mauricien. In principle, the rules contained in the Bill do not derogate from Articles 371 through 387 of the Mauritian Civil Code, they complement it. The same rule applies to the relationship between the Bill and the Divorce and Judicial Separation Act. ${ }^{7}$ In other words, the Bill does not aim at modification of legal provisions in the field of the substantive Mauritian Civil law. The two sets of rules are meant to coexist.

2.2 A Brief Overview and a Critical Analysis of Articles of the Mauritian Civil Code pertaining to Guardianship Rights (autorité parentale) (Articles 371 through 387)

Articles 371 to 387 of the Mauritian Civil Code, which Section 3 (2) of the Children's Bill refers to, address numerous issues pertaining to the parents' guardianship rights (autorité parentale). Article 371 of the Mauritian Civil Code contains a moral proclamation that "children, at all ages, owe honour and respect to their father and mother". ${ }^{8}$ Article 371.1 of the Code addresses the issue of the length of the parents' guardianship rights ${ }^{9}$ and article 371.2 provides us with the information on whom the above mentioned rights are bestowed (Courbe \& Gouttenoire, 2017, p. 489; Fenouillet, 2019, p. 526). ${ }^{10}$ Article 371.3 of the Mauritian Civil Code prohibits to a minor to leave the parental home without his parents' consent. ${ }^{11}$ However, Judge in Chambers may, in very exceptional circumstances, grant a permission to a minor to leave the parental home. ${ }^{12}$

\footnotetext{
${ }^{6}$ Cass. ch. mixte, 27 February 1970 number of pourvoi: 68-10276 and Cass. crim. 17 March 1970 number of pourvoi: $69-91040$.

7 The Divorce and Judicial Separation Act of 1982 (Act $n^{\circ}$ 20/1981) contains procedural rules on divorce and judicial separation.

8 The lack of respect of this legal provision may amount to a civil fault (Article 1382 and 1383 of the Mauritian Civil Code) and bestow upon the parents the right to ask for compensation of their moral and material prejudice.

9 "He remains under their authority until his majority or his emancipation by marriage".

10 "The authority belongs to the father and mother to protect the child in his safety, his health, his morality. They have the right and duty to care of, supervise and educate child".

11 "Subject to special provisions derogating from the rules laid down in this article, a child may not leave the family home without the permission issued by his father and mother and may not be removed from it, except in cases of necessity determined by law".

12 "However, the Judge in Chambers may authorize a child to leave the family home, at the request of one of the parents, when the abusive refusal of the other parent is not justified by the interest of the child".
} 
This important exception aims at helping the child to avoid physical or psychological violence of his parents that might threaten the development of the child.

Article 371.4 of the Mauritian Civil Code guarantees the right of every child to maintain a personal relationship with his ancestors (his grandparents for instance). ${ }^{13}$ Thus, a child has the right to stay at his grand-parent's home and to write letters to them (Fenouillet, 2019, p. 528).

Article 371.5 of the Mauritian Civil Code sets out the principle according to which siblings are not to be separated, save when there are special circumstances justifying such a separation (for example, the impossibility to avoid the separation or when the interest of a child requires the separation). ${ }^{14}$ Thus, it may occur that the behaviour of one of the siblings is seriously disrupted and it may appear to be in the best interest of that child to be entrusted to a specialized institution in order to help him to improve his behaviour.

Articles 372 and following of the Mauritian Civil Code address the issue of the exercise of the guardianship rights over a minor. It has to be highlighted that those guardianship rights enable the parents to decide on the child's lifestyle, his relationships and occupations (Fenouillet, 2019, p. 527; Garrigues, 2018, p. 522 et seq.). Article 372.1 of the Code sets out the principle of the common exercise by both father and mother of the guardianship rights (Garrigues, 2018, p. 520). ${ }^{15}$ However, it may occur that even when parents are still formally married, they are de facto separated. The Judge in Chambers will decide which parent he will bestow upon guardianship rights and his decision will be based on the best interest of the child. ${ }^{16} \mathrm{~A}$ similar rule is provided for in Article 373.2 of the Mauritian Civil Code in case of divorced parents. ${ }^{17}$ Moreover, even when the two parents live under the same roof, they disagree sometimes on how the guardianship rights should be exercised. In that case, the Judge in Chambers will make a decision on that issue and take into consideration previous practice on the same issue. If there is not any previous practice, the Judge in Chambers, seized by one of the parents, will decide in the best interest of the child (Article 372.1 of the Mauritian Civil Code). ${ }^{18}$

Article 372.2 of the Mauritian Civil Code protects third persons who act in good faith: those persons may legitimately consider that a parent acting alone and accomplishing an act pertaining to the person of the child has obtained the previous consent of the other parent. For instance, when a parent makes a contract with a private lessons teacher for the benefit of the former's child, the latter may assume that the above mentioned contract has been approved by the other parent.

\footnotetext{
13 "Children have the right to maintain personal relationships with their ancestors. Only the best interests of the child can hinder the exercise of this right". If it is in the best interests of the child, the Supreme Court sets the terms of the existence of the relationship between the child and a third party, whether a parent or not.

14 "A child must not be separated from his brothers and sisters, unless this is not possible or if his interest requires another solution."

15 "During the marriage, the father and mother exercise jointly their guardianship rights".

16 "However, in the event of de facto separation of father and mother, the Judge in Chambers, seized by one of the spouses, or the Supreme Court when there is a litigation between the two spouses, will rule on the custody of the child, taking into account exclusively the advantage and the interest of the child. Guardianship rights are then exercised by the parent who has been entrusted with custody, and the other parent will keep the visitation rights."

17 "If the father and mother are divorced (...) guardianship rights are exercised by the one of them who the Supreme Court entrusts with the custody of the child, and the other keeps the visitation rights".

18 "If the father and mother cannot agree on what is the best interests of the child, the practice they had previously been able to follow on similar occasions will be their rule. In the absence of such a practice or in the event of a dispute over its existence or its merits, the most diligent spouse may seize the Judge in Chambers who will rule on the issue after having attempted to reconcile the parties."
} 
Article 373 of the Mauritian Civil Code provides for the cases in which the guardianship rights may by definitely or temporarily lost. Thus, the above mentioned rights will be definitely or temporarily lost when:

- $\quad$ one of the parents is unable to express his will, due to his incapacity, his absence, his remoteness or any other cause;

- $\quad$ a judgment of revocation (withdrawal) has been pronounced against a parent, for those rights which have been taken away from him;

- $\quad$ a parent has been sentenced for abandonment of a child.

The Mauritian Civil Code gives always the priority to the idea that guardianship rights should be exercised at least by the father or the mother of a child. Thus, Article 373.1 of the Code stipulates that when one of the parents has died or one of the cases provided for in the above mentioned Article 373 of the Code is applicable, the other parent will exercise the guardianship rights. However, it may happen that a child does not have a parent able to exercise the guardianship rights. According to Article 373.3 of the Mauritian Civil Code when there is not a father or a mother able to exercise the guardianship rights, an official guardian will be assigned to a child. ${ }^{19}$

Article 374 of the Mauritian Civil Code addresses the issue of exercise of guardianship rights over a natural child whose parents are not married from the legal point of view. ${ }^{20}$ As we have already explained, both parents will exercise, in principle, jointly guardianship rights over a legitimate child whose parents were married at the moment of his birth. This rule is derived from the automatic establishment of the filiation (parental) link between a child and both parents, and especially his father. On the other hand, the establishment of the filiation link is not automatic regarding a natural child whose father and mother have to recognize him ${ }^{21}$. Only the parent who has recognized the child and has established the filiation link will be able to exercise guardianship rights over a minor ${ }^{22}$. Where both parents have recognizes the natural child born out of marriage, they will exercise jointly the above mentioned rights if they live as husband and wife (under the same roof) tough they are not formally married. In all other cases, one of them will exercise the guardianship rights and the other will have the right of visitation.

Articles 375 through 380 of the Mauritian Civil Code address the issues, which are practically important, of deprivation and partial withdrawal of parental authority (guardianship rights) (Fenouillet, 2019, p. 555 et seq.).

According to Article 375 of the Mauritian Civil Code, "a father and a mother who are convicted, either as perpetrators, co-perpetrators or accomplices of a crime or a

\footnotetext{
19 "If neither father nor mother remains in a position to exercise parental authority, there will be a case for the opening of guardianship."

20 "Parental authority is exercised, over a natural child, by father or mother, who has voluntarily recognized it, if it has been recognized by one of them only.

If the father and mother, who have both voluntarily recognized the natural child, lead a common life and live in the same residence, parental authority is exercised jointly by the two, according to the rules established by Articles 372 to 373-1.

If the fathers and mother who have both voluntarily recognized the natural child do not live in the same residence, parental authority is exercised by the one of them with whom the child usually lives, the other has the visitation rights.

In case of a dispute, in particular following the separation of the father and mother, the Supreme Court, at the request of the father or the mother rules on the custody of the natural child, taking into account exclusively the advantage and interest of it. The Supreme Court may in particular, for the greater benefit of the natural child, entrust the care of the latter to another parent or to a third person who has accepted this office."

${ }^{21}$ Articles 336 and 339 of the Mauritian Civil Code.

22 The same legal rules apply to the situation where the link of filiation is established by a Court's decision (Article 374. 1 of the Mauritian Civil Code): "The same rules apply, in the absence of voluntary recognition, when the link of filiation is established in a judgment, either towards both parents, or towards only one of them."
} 
misdemeanour committed against the person of their child, or as co-perpetrators or accomplices of a crime or a misdemeanour committed by their child, may be deprived of parental authority (guardianship rights)". However, conviction pronounced by criminal court is not the only ground for deprivation of guardianship rights as per the Mauritian Civil Code. Thus Article 376 of the Civil Code stipulates: "apart from any criminal conviction, a father and a mother who, either by ill-treatment, or by pernicious examples of habitual drunkenness, notorious misconduct or delinquency, or by lack of care or lack of direction, clearly endanger the safety, health or morals of a child may be deprived of parental authority (guardianship rights)" (Fenouillet, 2019, pp. 556-557; Garrigues, 2018, p. 548). Article 376 stipulates also that the action for deprivation of guardianship rights may be brought before the Supreme Court "either by the Attorney General, or by the father, mother or another family member of the child or by his guardian". This rule reflects the idea that the protection of the child is a matter of public interest and the circle of persons who, as per the Civil Code, may request deprivation of guardianship rights is wide.

Article 377 of the Mauritian Civil Code provides us with more precisions as to the scope of the deprivation of guardianship rights. The deprivation may be total, i.e. a parent is deprived of all elements, patrimonial and personal, of the parental authority, save a different decision of the Court. The deprivation is applied to all minor children already born or to be born of that parent. Article 377 of the Code adds that the deprivation of guardianship rights exempts a child from the maintenance obligation, by derogation from Articles 205 through 207 of the Civil Code, ${ }^{23}$ but the Court's decision on deprivation of guardianship rights may set another rule and uphold the above mentioned obligation. Article 378 of the Mauritian Civil Code sets out the rule of partial withdrawal of parental authority (guardianship rights). In other words, the deprivation of parental authority is not necessarily total; it may be partial (Fenouillet, 2019, p. 557). ${ }^{24}$

From the procedural point of view, the Supreme Court of Mauritius must, as per Article 379 of the Mauritian Civil Code, while pronouncing the deprivation or the partial withdrawal of guardianship rights, designate another parent or a third person (if the other parent is deceased or if he has lost the exercise of parental authority) who accepts this charge, and the above mentioned parent or the third person will assume guardianship of a child and the Court will determine the extent of his powers.

Article 380 of the Mauritian Civil Code stipulates that a parent who has been deprived, totally or partially, of guardianship rights, may request the Supreme Court to restore his guardianship rights in whole or in part. Article 380 of the Civil Code imposes upon the applicant the obligation to "justify new circumstances" which might account for the reinstatement of his guardianship rights. Those new circumstances pertain, in principle, to a positive change in that parent's life that provides a sufficient guarantee that he will take good care of a child. In order to ensure the seriousness of the request for reinstatement of guardianship rights, Article 380 of the Code stipulates that "the request for reinstatement of rights can be made only one year at earliest after the decision declaring deprivation or partial withdrawal has become irrevocable". Where the request for

\footnotetext{
${ }^{23}$ Article 205 of the Mauritian Civil Code stipulates that "children owe food to their parents, and other ancestors who are in need". Article 206 adds that "the sons-in-law and daughters-in-law also owe, in the same circumstances, maintenance to their stepfather and stepmother; but this obligation ceases, $1^{\circ}$ when the stepmother has celebrated a new marriage, $2^{\circ}$ when the spouse who produced the affinity, and the children resulting from his union with the other spouse died". Finally, according to Article 207 of the Mauritian Civil Code "the obligations resulting from these Articles are reciprocal".

24 "The judgment may, instead of total deprivation, be limited to declaring a partial withdrawal of rights, and pertain to the elements specified in it. It can also be decided that the total deprivation or partial withdrawal will have effect only with regard to some of the children already born."
} 
reinstatement of rights has been rejected, a new request for reinstatement of rights may be submitted to the Supreme Court after a further period of one year.

Article 380 of the Mauritian Civil Code is a rare situation where the Bill derogates from the Civil law legislation. Section 26 (1) of the Children's Bill stipulates that "any person who is convicted for an offence committed on a child under this Bill or under sections 249 and 250 of the Mauritian Criminal Code, shall be interdicted from any guardianship -(a) for a period not exceeding 5 years in the case of any offender; or (b) for a period of 10 years where the offender is a parent of a child". Thus, if the Bill is passed in the Mauritian Parliament, when a father and a mother are convicted, either as perpetrators, co-perpetrators or accomplices of a crime or a misdemeanour committed against the person of their child, they will be allowed to ask for the reinstatement of their guardianship rights after a period up to 10 years instead of a period of one year. We are of the opinion that the proposed rule is too harsh not only on parents but also on a child because it is not in his best interest to be deprived of the possibility to have his parents as guardians for a long period of time up to 10 years. People can change, and one year is a sufficient period of time to give every parent the opportunity to change positively in his life and to prove it to the Judge in Chambers in order to get back his guardianship rights. The absolute deprivation of guardianship rights for a period of eight or nine years takes away the opportunity that the parent who has made considerable efforts in his life and has changed positively will have an opportunity to take care of his child, which would be, without any doubt, the best solution for the child.

It should be underlined that Section 26 (2) of the Bill contains an explicit referral to Articles 371 through 387 of the Code Civil Mauricien. When an offence has been committed by the father or the mother of a child, the offender will be deprived of his rights and advantages provided for by Articles 371 through 387 of the Mauritian Civil Code. Thus, Section 26 of the Bill and Articles 371 through 387 of the Mauritian Civil Code complement each other.

Articles 381 and following of the Mauritian Civil Code addresses the issue of guardianship rights of the parents over the property of their minor child. According to Article 380 of the Mauritian Civil Code, the administration and enjoyment of a child's property is bestowed upon his father and mother (Chouk, 2017, p. 417 et seq.; Courbe \& Gouttenoire, 2017, p. 500; Garrigues, 2018, p. 529). Article 382 of the Civil Code adds that the legal administration of their minor child's property is exercised by the father and the mother when they exercise parental authority (guardianship rights) in common. In other cases, the guardianship rights over the minor's property will be exercised either by the father or by the mother (Fenouillet, 2019, p. 528 et seq.). ${ }^{25}$ Where the guardianship rights are exercised in common by both parents, every third person acting in good faith, ${ }^{26}$ for instance a buyer of an object belonging to their minor child may consider that the parent acting alone has the necessary power to make a contract which qualifies as acts of administration (actes d'administration) (Article 391 (3) of the Mauritian Civil Code) (Garrigues, 2018, p. 529). All other contracts that are not considered as acts of administration, and in particular the acts of disposition ${ }^{27}$ of their minor child's movable property, such as contract of sale or contract of exchange, require the consent of both parents, otherwise the contract will be null and void (Fenouillet, 2019, p. 533). Moreover,

\footnotetext{
25 See also Article 389 of the Mauritian Civil Code.

${ }^{26}$ In fact, he does not know that the other parent disagrees with the contract made alone by the parent who detains an object belonging to their minor child.

27 The acts of disposition may be defined as those acts, which affect the substance of the property of the minor child.
} 
the most serious contracts in terms of financial consequences, such as sale of minor child's immovable property require not only the consent of both parents but also the prior authorization of the Judge in Chambers (Article 394 of the Mauritian Civil Code) (Garrigues, 2018, p. 530; Hauser, 2015, p. 354). The Mauritian Civil Code remains silent on the legal rules applicable to the situation where the legal administration of the minor child's property is bestowed upon one parent only. It seems that the best solution would be to allow the above mentioned parent to make the contracts alone which qualify as acts of administration as well as acts of disposition of minor's movable property. On the other hand, the acts of disposition of minor's child immovable property, given their financial seriousness, would require not only the consent of the parent who exercise the guardianship rights but also the consents of the Judge in Chambers (Fenouillet, 2019, pp. 536-537).

Article 383 of the Mauritian Civil Code stipulates that legal enjoyment of a minor's child property "is attached to legal administration: it belongs either to both parents jointly, or to that of the father and mother who are in charge of the administration". In addition, according to Article 384, "the right of enjoyment ceases: 1. As soon as a child is sixteen years old; 2. For the causes which put an end to parental authority, or even more specifically for those which put an end to legal administration; 3. For the causes which lead to the extinction of all usufruct" (Courbe \& Gouttenoire, 2017, p. 500; Garrigues, 2018, p. 531).

Finally, Article 387 of the Mauritian Civil Code excludes some forms of minor's property from the legal enjoyment conferred to the parents. Thus, "legal enjoyment does not extend to the property which a child can acquire through his work, nor to that which is given or bequeathed to him under the express condition that the father and mother will not enjoy it" (Fenouillet, 2019, pp. 530-531). ${ }^{28}$

\section{BEST INTEREST OF A CHILD}

\subsection{The Proclamation of the Best Interest Principle in the Children's Bill of 2019}

Section 5 of the Children's Bill of 2019 sets out the best interest principle (Boulanger, 2006, p. 554 et seq.; Courbe \& Gouttenoire, 2017, p. 491). ${ }^{29}$ Thus, Section 5 (1) of the Bill stipulates that "the best interest of a child shall, in respect of any matter concerning the child, be paramount and be the primary consideration by any person, Court, institution or other body". Section 5 (2) of the Act adds that "(...), every person, every Court, every institution or any other body shall, in relation to any matter concerning a child - (a) respect, protect, promote and fulfil the rights and the best interests of the child; (b) respect the inherent dignity of the child; (c) treat the child fairly and equitably; (d) protect the child from discrimination; (e) bear in mind the needs of the child for his development, including any special needs which may be due to a disability; (f) where appropriate, give the child's family member an opportunity to express his views; (g) as far as possible, act promptly", etc. The principle proclaimed in Section 5 (1) of the Bill as well as the guidelines given in Section 5 (2) of the Bill are greatly respected in the Mauritian Civil law legislation.

\footnotetext{
28 See also Article 390 (3) of the Mauritian Civil Code. - Cass. $1^{\text {st }}$ Ch. 10 $0^{\text {th }}$ June 2015, Recueil Dalloz, p. 1318; Cass. $1^{\text {st }}$ Ch. $11^{\text {th }}$ Feb. 2015, Recueil Dalloz, 2015, p. 488.

29 See: Cass. $1^{\text {st }}$ Ch. 22 Nov. 2005, Recueil Dalloz, 2006, comment Gallmeister I., p. 554.
} 


\subsection{Conformity of the Mauritian Civil Code with the Best Interest of a Child principle}

Article 371.3 of the Mauritian Civil Code prohibits a minor from leaving the parental home without his parents' consent. ${ }^{30}$ However, Judge in Chambers may, under very exceptional circumstances, grant a permission to a minor to leave the parental home. ${ }^{31}$ As already mentioned before, the exception to the rule aims at helping the child to avoid physical or psychological violence of his parents which might threaten the development of the child.

Article 371.4 of the Mauritian Civil Code guarantees the right of every child to maintain personal relationship with his ancestors (his grandparents for instance) ${ }^{32}$. The same right may be bestowed upon the so called "third persons", such as relatives or homosexual partners of a parent, and in particular when the above mentioned third party has resided permanently with the child and one of his parents has provided for his education, maintenance or installation and has established lasting emotional ties with him $^{33}$. In a gist, as long as the contact with third persons may contribute to the good development of a child, the Mauritian Legislator considers that it is in the best interest of the child to maintain personal relationship with that third person. ${ }^{34}$

Article 371.5 of the Mauritian Civil Code sets out the principle according to which siblings are not to be separated, save when there are special circumstances justifying such separation (for example, the impossibility to avoid the separation or when the interest of a child requires the separation). ${ }^{35}$ For example, it may be in the best interest of the child to be separated from his siblings when his education or a sports training abroad requires it.

It may occur that even if they are still formally married, the child's parents are separated. The Judge in Chambers will decide upon which parent he will bestow guardianship rights and his decision will be based on the best interest of the child. ${ }^{36}$ In other terms, he will take into consideration all the circumstances of the case and decide which parents provide more guarantees for the good development of the child. It may also occur that even when two parents live under the same roof, they disagree on how the guardianship rights should be exercised. In that case, while deciding on the request, the Judge in Chambers will take into consideration previous practice on the same issue and if there is not, the Judge in Chambers, seized by one of the parents, will decide in the

\footnotetext{
30 "Subject to special provisions derogating from the rules laid down in this article, a child may not leave the family home without the permission issued by his father and mother and may not be removed from it, except in cases of necessity determined by law."

31 "However, the Judge in Chambers may authorize a child to leave the family home, at the request of one of the parents, when the abusive refusal of the other parent is not justified by the interest of the child".

32 "Children have the right to maintain personal relationships with their ancestors. Only the best interests of the child can hinder the exercise of this right."

If it is in the best interests of the child, the Supreme Court sets the terms of the existence of the relationship between the child and a third party, whether a parent or not."

${ }^{33}$ Cass. $1^{\text {st }}$ Ch. 6 nov. 2019, Actualité Juridique Famille, 2019, comment Saulier M., p. 649.

${ }^{34}$ Cass. $1^{\text {st }} 27$ May 2010, Revue Trimestrielle de Droit Civil, comment Hauser J., 2010, p. 548.

35 "A child must not be separated from his brothers and sisters, unless this is not possible or if his interest requires another solution."

36 "However, in the event of de facto separation of father and mother, the Judge in Chambers, seized by one of the spouses, or the Supreme Court when there is a litigation between the two spouses, will rule on the custody of the child, taking into account exclusively the advantage and the interest of the child. Guardianship rights are then exercised by the parent who has been entrusted with custody, and the other parent will keep the visitation rights". - Comp. with: Cass. $1^{\text {st }}$ Ch. 13 mars 2007, Revue critique de droit international privé, 2007, comment Gallant E., pp. 603 et seq.
} 
best interest of the child (Article 372.1 of the Mauritian Civil Code). ${ }^{37}$ Once again, the Judge in Chambers will base his decision on what is the best for the physical and psychological development of the child. Thus, in case of disagreement between the parents as to the religious rites pertaining to the child, the Judge in Chambers will take into consideration all the circumstances and make a decision in conformity with the best interest of the child. ${ }^{38}$

Since 2011, Mauritian Civil law contains a new form of divorce, i.e. divorce by mutual agreement (Articles 238-3 et seq.), which is based on an agreement of the exspouses on all aspects of divorce and has to be approved (homologué) by a Judge. According to Article 238-5 of the Mauritian Civil Code, the Judge can refuse the homologation of the divorce agreement of the ex-spouses and refuse to pronounce the divorce if he thinks that the agreement does not sufficiently protect the interests of the children or the interests of one of the spouses. The Judge may also delete or modify the clauses of the above mentioned agreement when it appears to him to be contrary to the interests of the children or of one of the spouses. Thus, every time when an agreement of the spouses pertaining to the residence of the child, the exercise of the guardianship rights, the financial contribution to the maintenance of the child, etc. does not sufficiently protect the health and the development of the child, the Judge will refuse to approve the divorce agreement.

According to Article 242 of the Mauritian Civil Code, in case of the divorce other than the divorce by mutual agreement when "there are minor children, the Judge in Chambers, decides on their custody, as well as on the right of visit and accommodation", 39 while taking into account exclusively the advantages and interests of the children. ${ }^{40}$ Moreover, the Judge in Chambers "may entrust the children to any of the spouses or may order, for the greater benefit of the children, that all or some of them are to be entrusted to other family members or even to a third person who accepts this charge". The divorce judge will take into consideration all appropriate circumstances in order to evaluate the best interest of a child. For instance, the best interest of an autistic child may justify that in the event of the divorce, the judge chooses to entrust the custody of the child to one parent rather than to the other. Guardianship rights will be bestowed upon the parent who gives more guarantees for the best possible development of the autistic child. However, we have to underline the fact that in Mauritian Civil law there is a strong legal presumption that it is in the interest of a very young child to be entrusted to his mother. Thus, "custody of children under the age of five must always be bestowed upon the mother, subject to exceptional circumstances likely to compromise their safety or health". The rule set out in Article 242 of the Mauritian Civil Code is confirmed in Article 261 of the same Code. This Article stipulates that the Supreme Court of Mauritius in cases of divorce other than the divorce by mutual agreement, "rules on the custody of children, while taking into account exclusively their advantages and interests. The children are entrusted to one spouse, unless, after having heard the Attorney General's Office, the Supreme Court orders, for the

\footnotetext{
37 "If the father and mother cannot agree on what is the best interests of the child, the practice they had previously been able to follow on similar occasions will be their rule. In the absence of such a practice or in the event of a dispute over its existence or its merits, the most diligent spouse may seize the Judge in Chambers who will rule on the issue after having attempted to reconcile the parties".

${ }^{38}$ Cass. $1^{\text {st }}$ Ch. 23 Sept. 2015, Recueil Dalloz, 2015, p. 1952.

39 The exercise of this right may be denied to the parent on whom the guardianship rights have not been bestowed, when it is in the best interest of a child: Cass. $1^{\text {st }}$ Ch. 9 Feb. 2011, Actualite Juridique Famille, 2011, comment Siffrein-Blanc C., p. 207 ; Cass. $1^{\text {st }} 24$ Oct. 2000, Revue Trimestrielle de Droit Civil, 2001, comment Hauser J. p. 126.

40 The same rule is applied by the French Court of Cassation: Cass. $1^{\text {st }}$ Ch. $12^{\text {th }}$ Sept 2019 , Actualité Juridique Famille, comment Saulier M., p. 526.
} 
greater benefit of the children, that all or some of them will be entrusted to another family member or even a third person who accepts this charge". Once again, Article 261 of the Mauritian Civil Code reminds that "the custody of children under the age of five must always be bestowed upon the mother, subject to exceptional circumstances likely to compromise their safety or health". In principle, the siblings are not separated by court's decision (Fenouillet, 2019, p. 529), because from the psychological and emotional point of view, it is in their best interest to grow together.

Article 347 of the Mauritian Civil Code stipulates that at the request of one or both adopters a simple adoption may be converted by the Judge in Chambers into a full adoption when the conditions required by Articles 364 to 366 are met and "when this conversion seems to be in the best interests of the child". In this particular case, the interest of the child whose adoption is being converted is to be treated by the Civil law in the same manner as the biological children of the adopter (inheritance rights).

According to Article 353 of the Mauritian Civil Code, "at the adopter's request and after having heard the request, the adoption is pronounced by the Judge in Chambers, who checks whether the conditions set by the law are fulfilled and whether the adoption is in the best interests of the child. If he considers it necessary, the Judge in Chambers may postpone the pronouncement of adoption by imposing on the applicant a probation period, the duration of which will not exceed six months, during which the latter must host at his home the child that he intends to adopt". The decision rejecting the request for adoption must be justified and has to mention expressly the text of the legal provisions on which it is based or the reasons why the adoption was not considered to be in the best interests of the child. It is easy to understand that the best interest of the child here is to be adopted to a person or the persons who will provide the sufficient guarantees for the adequate physical and psychological development of the child.

We have to underline the fact that in Mauritian Civil law the best interest principle will be applied even if there is no specific provision in the Mauritian Civil Code which mentions it. For example, as already mentioned before, all contracts that are not considered as acts of administration, and in particular the acts of disposition ${ }^{41}$ of their minor child's movable property, such as contract of sale or contract of exchange, require the consent of both parents, otherwise the contract will be null and void. Parents have to take their decision to sell or to exchange a movable property of their minor child only if it is in his best interest, for example in order to pay his medical bills or to pay for his studies in a private school. When the parents disagree on whether the act of disposition is in the best interest of their child or not, the decision will be made by the Judge in Chambers who will take into consideration the best interest of the child (article 391 (2) of the Mauritian Civil Code) (Fenouillet, 2019, p. 533). Moreover, even if the Mauritian Civil Code does not contain an express proclamation, it is certain that the best interest of the child is to live and be brought by his biological family, the total or partial withdrawal of guardianship rights being an exceptional measure (Marguénaud, 2019, p. 814). The best interest of a child is always evaluated in concreto by the Judge, i.e. the Judge has sovereign discretion while deciding what is, under given circumstances, in the best interest of the child. ${ }^{42}$

On the other hand, the Code Civil Mauricien provides examples where the best interest of a child is not taken into consideration in a satisfactory manner. Article 340 of the Mauritian Civil Code stipulates that paternity of a child born outside marriage can be

\footnotetext{
${ }^{41}$ The acts of disposition may be defined as those acts which affect the substance of the property of the minor child.

42 Plen. Ass. 4 ${ }^{\text {th }}$ Oct 2019, Actualité Juridique Famille, 2019, comment Houssier J. p. 592.
} 
judicially declared only if there is one of the situations listed in the above mentioned Article, i.e. in case of abduction or rape when the time of the abduction or rape coincides with the time of the conception of the child; in case of seduction accomplished by means of fraudulent maneuvers, abuse of authority, promise of marriage or engagement; in case where there are letters or some other private writing emanating from the alleged father and from which may be deduced an unequivocal confession of paternity; in case where the alleged father and mother lived in a state of notorious cohabitation during the legal period of conception of the child; in case where the alleged father provided or participated in the maintenance and education of the child as a father. Thus, Article 340 of the Mauritian civil Code does not allow the mother of a child born outside marriage, conceived in an ephemeral relationship between the mother and a man, to bring an action for the establishment of paternity before a court against that man who has never hinted in a writing that he is the father of the child. This assertion has been explicitly made in the judgment of the Supreme Court of Mauritius Legueff $v$ Dhunny $\left(29^{\text {th }} \text { May } 2014\right)^{43}$. It does not seem that the ephemeral nature of the relationship between the mother and the father of a child is a sufficient reason to refuse the establishment of the filiation link between the father and the child and the solution set out in Article 340 of the Mauritian Civil Code does not seem, in our opinion, to be in the best interest of the child whose best interest is to have a father from the legal point of view. The link of paternal filiation bestows upon the child several important rights, provided for in the Mauritian Civil Code, such as right to paternal name, inheritance rights, right to maintenance, right to be provided education, etc.

\section{PROHIBITION OF DISCRIMINATION OF CHILDREN}

\subsection{Prohibition of Discrimination of Children in the Children's Bill of 2019}

Section 8 of the Mauritian Children's Bill of 2019 provides for the nondiscrimination of children. Thus, according to Section 8 (1) of the Act, "no person shall discriminate against a child on the ground of the child's or child's parents race, caste, place of origin, political opinion, colour, creed, sex, language, religion, property or disability". The non-respect of the above mentioned rule is a criminal offense sanctioned by a fine non exceeding 10000 rupees and by the imprisonment up to 2 years. However, the above mentioned illegal discrimination of children generates also Civil law consequences.

\subsection{Tort Law Consequences of the Discrimination of Children}

The lack of respect of the prohibition of discrimination may also entail Civil law consequences, more precisely the Tort law consequences. Thus, the illegal discrimination of a child may generate the tort liability of the author of that discrimination towards the child who is a victim of such discrimination. This liability is based on a fault committed by the author of the act of discrimination. In Mauritius, the legal notion of civil fault is defined in Articles 1382 and 1383 of the Mauritian Civil Code. Article 1382 of the Code stipulates that "any act of a man, which causes prejudice to another, obliges the person by the fault of which it occurred, to repair it". Moreover, Article 1383 of the Mauritian Civil Code adds that "everyone is responsible for the prejudice which he caused not only by his deliberated act, but also by his negligence or his carelessness". In Mauritian Civil law the fault may consist of the violation of an obligation expressly laid down by law. Thus, if

432014 SCJ 191.

BRATISLAVA LAW REVIEW

Vol. 4 No 1 (2O2O) 
the Children's Bill of 2019 becomes an Act of Parliament in the future, the violation of the obligation of non-discrimination of children will certainly constitute a civil fault which will account for the tort liability of the author of the act of discrimination. More broadly, in Mauritian Civil law the fault results from any violation of the general principle of not harming unfairly others (Egéa \& Tranchant, 2018, p. 123; Flour, Aubert, \& Savaux, 2011, pp. 118-120; Jourdain, 2014, pp. 46-52; Terré, Simler, Lequette, \& Chenede, 2019, pp. 1030-1031). In Mauritian Civil law a civil fault stems from the comparison of the behaviour of a subject of law with the behaviour considered to be correct and from the conclusion that there is a deviation from the behaviour which is considered as the correct behaviour. ${ }^{44}$ The existence of a civil fault is evaluated in abstracto: ${ }^{45}$ the behaviour of the author of the prejudice will be compared to the behaviour of an abstract and average person, commonly called "normally prudent and advised" person (Egéa \& Tranchant, 2018, p. 124; Flour et al., 2011, pp. 136-137; Terré et al., 2019, p. 1037). There is a civil fault when the behaviour of the author of the prejudice is not in conformity with the behaviour of an abstract and average person ${ }^{46}$. It is certain that the act of unfair discrimination of a child is not the behaviour that a "normally prudent and advised" person would have and thus constitutes a civil fault.

The above-analysed civil fault of the author of an act of discrimination may cause either material or moral prejudice to a child. The Mauritian civil law allows compensation for both forms of prejudice.

According to the broadest definition, in Mauritian Civil law prejudice consists of an injury to a legally protected interest. More concretely, the prejudice may be defined either as a lesion of the property of a person (patrimonial prejudice) or an injury of extrapatrimonial interests of a person (moral/extra-patrimonial prejudice). The material prejudice is the one that may be financially assessed. Thus, the patrimonial prejudice may consist of a reduction in the assets of the victim of the prejudice ${ }^{47} \mathrm{~A}$ discriminated child may ask for compensation where an act of illegal discrimination has entailed the reduction in his assets. For example, a child was unable to enroll in a private school because of an act of illegal discrimination as per Section 8 of the Children's Bill. The total fee for the studies in that school is about 800000 Mauritian rupees. The child had to be enrolled in another private school where the total fee is 1300000 rupees. The difference between the two fees of 500000 rupees constitutes the material prejudice (the reduction of the child's assets) that stems from the act of illegal discrimination (civil fault). The minor (or his legal representative, a father or a mother) may bring an action before the court and ask for the compensation of the above mentioned material prejudice.

\footnotetext{
44 Those basic rules have been set out in the judgment of the Supreme Court of Mauritius Mohun v. Jugnah \& ANOR of 2002 and in the judgment of the Intermediate Court Ramchurn Uma Parvati \& ORS v. Sahadeo Ashok \& ANOR of 2008

45 See: the judgment D. Hurnam v. D. K. Dabee, handed down by the Mauritian Intermediate Court in 2010.

${ }^{46}$ In the system of evaluation in abstracto of the civil fault, personal characteristics of the author of the prejudice are not taken into account. However, there are a few concrete elements to be taken into account. These elements must not be strictly personal to the author of the damage. Thus, in the system of evaluation in abstracto of the civil fault, a model of comparison, i.e. an abstract diligent and prudent person is the person carrying out the same activity as the person whose behaviour is analysed. For instance, the behaviour of a doctor will be compared to the behaviour of an abstract prudent and wise doctor placed in the same circumstances. Thus, professional qualification is a concrete element which penetrates the abstract evaluation of the fault in Mauritian civil law. In addition, the circumstances of the concrete case are also taken into account in order to determine what an abstract prudent and wise person would have done in the same circumstances.

47 See for instance: Cass. Comm. Ch. 20th Nov. 2012, Revue des sociétés, 2013, comment Tabourot-Hyest, p. 430 ; Cass. $2^{\text {nd }}$ Ch. 8 April 2004, Revue du droit immobilier, 2005, comment Trébulle F. - G, pp. 321 et seq.
} 
The Mauritian civil law provides, under certain conditions, compensation for the loss of a chance. In other words, the loss of a serious chance of making a gain or avoiding a loss may be compensated. The French Court of Cassation, ${ }^{48}$ which is a persuasive authority in Mauritius, insists upon the seriousness of the loss of a chance. ${ }^{49}$ The same approach is taken by Mauritian courts. ${ }^{50}$ The concept of the loss of a chance may be very useful in case of illicit discrimination of a child as per Section 8 of the Children's Bill. For example, the civil fault (act of discrimination of a child) may sometimes entail for the child the loss of a serious chance ${ }^{51}$ to follow the educational path, which might give him better professional and financial opportunities in life. This loss may be financially evaluated and constitutes a form of material prejudice that may be compensated in Mauritian Civil law.

The Mauritian Civil law also provides for the compensation for moral prejudice. Moral (non-pecuniary) prejudice may be defined as an injury to non-pecuniary characteristics of a person. Simply put, moral prejudice consists of suffering of a victim. ${ }^{52}$ This suffering is sometimes psychological and other times it is physical. Moral (nonpecuniary) prejudice may stem from a violation of the right to honour (defamation), the right to a name (usurpation of the name) or the right to privacy (unauthorized disclosure). In the above mentioned cases the harm consists in the psychological suffering resulting from the violation of the aforementioned rights. It is easy to understand that a moral prejudice may result for a child who has been illicitly discriminated as per Section 8 of the Children's Bill. Such discrimination may entail a sharp psychological suffering of a child due to an attack on his honour. This psychological suffering may be compensated according to Mauritian civil law. ${ }^{53}$

\section{MARRIAGE OF CHILDREN}

\subsection{Prohibition of Forced Marriages of Children in the Children's Bill of 2019}

Section 9 of the Children's Bill of 2019 prohibits to force a child to marry either civilly or religiously. The non-respect of the above mentioned rule is a criminal offense sanctioned by a fine non exceeding 10000 rupees and by the imprisonment up to 2 years. This is clearly a criminal law provision. On the one hand, forced marriages are also

\footnotetext{
48 Cass. $2^{\text {nd }}$ Ch. 23 May 2019, Revue Trimestrielle de Droit Civil, 2019, comment Jourdain P., pp. 881 et seq.; Cass. Comm Ch. 13 th Feb. 2019, Recueil Dalloz, 2019.

49 In a judgment of November 21, 2006, the judges of the First Civil Chamber of the French Court of Cassation stressed the need for the seriousness of the loss of a chance: "(...) only constitutes a repairable loss of a chance, the current and certain disappearance of a favourable eventuality". Moreover, the judges of the First Civil Chamber of the French Court of Cassation stated in a judgment of March 22, 2012: "Whereas the loss of a chance is of a direct and certain nature each time that the disappearance of a favourable event is established (...)".

50 For instance, according to Mauritian Intermediate Court, there exists the loss of a serious chance if a candidate with the necessary skills and knowledge was unable to sit for an examination or competition due to the harmful event (civil fault). This reasoning was followed in the judgment of the Intermediate Court Calleechurn Ashwin Kumar's v. Bhoyro Satteedeo \& ORS of 2007. In this case, a pedestrian had been injured and had suffered a loss of physical capacity. The Intermediate Court's Magistrate awarded the plaintiff compensation for the loss of the opportunity and held: "Further no counter evidence has been adduced to disprove the assertion of the plaintiff that he had to attend treatment on a few occasions and that he could not complete his studies which can be assimilated to a "perte d'une chance".

51 The lost chance of a child is serious when a child possesses the necessary abilities to study in a programme to which he did not get access because of an act of discrimination.

${ }^{52}$ Cass. $2^{\text {nd }}$ Ch. 8 April 2004, Revue du droit immobilier, 2005, comment Trébulle F. - G, pp. 321 et seq.

53 See for example the judgment of the Supreme Court of Mauritius La Santinelle Ltd vS. J. R. Dayal 2000 SCJ 92, where the former Police Commissioner Mr Dayal has been compensated for the moral prejudice stemming from an insult made by a journalist.
} 
prohibited in Mauritian Civil law. On the other hand, marriage of a child is not always prohibited in Mauritian Civil law.

\subsection{Prohibition of Forced Marriages in the Mauritian Civil Code}

The treatment given to the forced marriages of children in the Children's Bill (a criminal offense) is in conformity with the prohibition of forced marriages in general, stipulated in Article 180 of the Mauritian Civil Code. Thus, Article 180 of the Mauritian Civil Code stipulates that "a marriage which has been celebrated without the free consent of both spouses or of one of them, can be attacked only by the spouses, or by one of the two whose consent has not been free" (on the issue of the time limit to take legal action and request the annulment of the marriage for violence: (Hontebeyrie, 2016, updated in 2020, par. 170). Sub-section 2 of Article 180 adds that "if there has been an error in the person (of one spouse - highlighted by author), or on the essential qualities of the person, the other spouse may request the nullity of the marriage". ${ }^{54}$ The nullity of the marriage entered into under the influence of violence is explained by the need to protect the personal freedom of every individual in Mauritius. In Mauritian law of marriage violence is defined as an evil by which one of the spouses is threatened regarding his person or his property. For example, it may happen that one spouse applies physical violence to the other before the celebration of the marriage and that the above mentioned violence incites its victim to enter into the marriage. Moreover, it may happen that one spouse utter threats to the other (death threats for instance) before the marriage is made and that those threats explain why the victim of threats has entered into the marriage (Lemouland, 2020, par. 111. 81). The evil by which one spouse threatens the other before the marriage must create in the latter's mind the fear of an evil whose realization would be, in the latter's eyes, relatively close (Lemouland, 2020, par. 111. 81). The Mauritian Civil law does not require that the evil by which one of the spouses is threatened is considerable, i.e. that it is objectively serious. It is sufficient that the object of the threat alters the will (to enter into the marriage) of the spouse who is the victim of the threat (Lemouland, 2020 par. 111. 81), and the victim of violence may request the annulment of the marriage. The author of the threat may be one of the future spouses or a third party (for instance, the parents of one of the spouses), it does not affect the possibility to ask for the annulment of the marriage. On the other hand, the victim of the object of the threat does not necessarily need to be one of the spouses, it may also be one of his relatives (ancestors, children, etc.). The above mentioned rules apply to all spouses in Mauritius, including the spouses who are still not of the age of 18 . On the other hand, currently there is no obstacle to the marriage of minors of the age of 16 or 17 , subject to the conditions laid down in the Mauritian Civil Code.

\subsection{Validity of Children Marriages in the Mauritian Civil Code}

Section 9 of the Children's Bill prohibits forced marriages of children without prohibiting the principle of children's marriage. On the one hand, in Mauritian Civil law the legal majority is acquired at the age of $18 .{ }^{55}$ However, the Mauritian Civil Code allows,

\footnotetext{
54 It has to be noted that Article 181 of the Mauritian Civil Code provides for the possibility to validate a forced marriage. Article 181 of the Code stipulates that "the application for nullification of marriage is not admissible, whenever there has been continuous cohabitation for six months since the spouse acquired full freedom of will or the error was recognized by him". The Mauritian Legislator has deduced, from the voluntary cohabitation of sufficient duration between the spouses, the intention to validate the forced marriage.

${ }^{55}$ Article 388 of the Mauritian Civil Code.
} 
under certain circumstances, marriages of children of the age 16 and 17. Thus, Article 145 of the Civil Code stipulates that "minors who are old less than 18 years but more than 16 years may enter into marriage with the consent of their father and mother or of the one of them who exercise exclusively parental authority (guardianship rights). This consent may be expressed either before the Civil Registrar, before a notary, or before the person authorized to celebrate marriage". The consent of one of the parents will suffice when the other has already deceased or when it is impossible for the other parent to express his will (Corpart I., 2015 par. 111; Lamarche \& Lemouland, 2014, par 249 et seq.). However, Sub-section 2 of Article 145 provides that "in the absence of a father and mother or of one of them who exercises parental authority, the Judge in Chambers may grant an exemption of age to the minor if it is in the latter's interest". We believe that the same rule has to be applied, i.e. the Judge in Chambers has to give his authorization for the marriage of a minor when the parents who exercise jointly their guardianship rights disagree on whether their minor child should enter into marriage or not. It seems that the intervention of the Judge in Chambers is a solid guarantee that minor will not enter into a marriage which would be contrary to his best interest.

Parents are supposed to give their consent to the marriage of their minor child with regard to a specific person. In other words, the parents' consent must indicate the name and surname, as well as the place of residence of the future spouse. A general and indefinite authorization would not suffice, "since it would not meet the objectives of protection of the child and his family that the law seeks" (Lamarche \& Lemouland, 2014, par. 273). Moreover, as long as the marriage is not celebrated, the parent may withdraw his consent and especially if he considers that his decision has been based on an inaccurate information pertaining to the other spouse (Lamarche \& Lemouland, 2014, par. 274).

The Mauritian Legislator has considered that parents who exercise the guardianship rights over their minor child are the most appropriate persons to decide whether the marriage of their child is in the best interest of the latter or nor. This is why it has to be highlighted that the parent's authorization is discretionary, i. e. the parents' decision is sovereign and does not have to be motivated. A child will not possess any legal remedy against the decision (refusal) of his parents (Lamarche \& Lemouland, 2014, par. 277).

\section{ILL-TREATMENT OF CHILDREN}

\subsection{Prohibition of the III-treatment of Children in the Children's Bill of 2019}

Section 10 of the Bill prohibits the ill-treatment of a child. According to Section 10 (1) of the Bill "no person shall ill-treat a child, or allow a child to be ill-treated so that the child suffers, or is likely to suffer, harm". Subsection (3) of the Section 10 adds that the non-respect of the above mentioned rule is a criminal offense sanctioned by a fine non exceeding 10000 rupees and by the imprisonment up to 2 years. The same idea is incorporated in Section 11 of the Bill according to which the corporal punishment of a child is prohibited. Section 11 (1) stipulates that "no parent or other person responsible for the care, treatment, education or supervision of a child shall inflict corporal or inflict humiliating punishment on the child as a measure to correct or discipline the child". Section 11 (2) of the Bill provides that the non-respect of the above mentioned rule is a criminal offense sanctioned by a fine not exceeding 10000 rupees and by the imprisonment up to 2 years. According to Section 11 (3) corporal or humiliation punishment is defined as any form of punishment which causes pain or suffering to a child through, but not limited 
to, the use of force or use of substances. It has to be noted that ill-treatment of a child entails not only the criminal law consequences defined in the Children's Bill but also the important Civil law consequences.

\subsection{Tort Law Consequences of the III-treatment of Children}

The lack of respect of the prohibition to ill-treat children entails not only the Criminal law consequences stipulated in Sections 10 and 11 of the Children's Bill of 2019 but also Civil law consequences. The ill-treatment of a child may generate the tort liability of the author of the act of ill-treatment towards the child who is a victim of such an illtreatment. This liability is based on a civil fault committed by the author of the act of illtreatment who has not acted in conformity with Articles 1382 and 1383 of the Mauritian Civil Code. If the Children's Bill of 2019 becomes an Act of Parliament in the future, the illtreatment of children will be contrary to Sections 11 and 12 of the Act and will certainly constitute a civil fault accounting for the tort liability of the author of the act of illtreatment. As already mentioned before, more broadly, in Mauritian law the civil fault results from any violation of the general principle of not harming unfairly others. As already explained, a civil fault results from the comparison of the behaviour of a subject of law with the behaviour considered to be correct and the conclusion that there is a deviation from the behaviour which is considered as the correct behaviour. ${ }^{56}$ The act of ill-treatment is considered to be incorrect behaviour from the point of view of Mauritian Tort Law: any reasonable and prudent person would consider it as inappropriate and incorrect.

The above-analysed civil fault of the author of ill-treatment may cause either material or moral prejudice to a child. Mauritian civil law allows compensation for both forms of prejudice. For instance, the material prejudice may consist of the reduction of the child's property: the child has to spend money on the payment of private clinic bills, medical drugs, etc. because of the injuries caused by the ill-treatment. On the other hand, the moral prejudice of a child, the victim of an ill-treatment, may be compensated and this prejudice consists of the moral suffering due to an attack on the honour of a child or of the physical suffering due to the suffered physical injuries.

\section{SURROGACY AND SALE OF CHILDREN}

\subsection{Prohibition of Surrogacy and Sale of Children in the Children's Bill}

Section 12 of the Children's Bill of 2019 provides for the offences pertaining to surrogacy and sale of children. Thus, Section 12 (2) of the Bill stipulates that "no person shall, for remuneration or by gift, for promise, by threat or through abuse of authority, incite any parent to abandon his child". Section 12 (3) of the Bill adds that "no person shall, for remuneration or any other consideration, act as an intermediary between a person wishing to adopt a child and any parent willing to abandon his child". The non-respect of the above mentioned rule is a criminal offense sanctioned by a fine non exceeding 10000 rupees and by the imprisonment up to 2 years. In other words, the Bill prohibits anyone to make a contract for delivery of an unborn or already born child.

\footnotetext{
56 Those basic rules have been set out in the judgment of the Supreme Court of Mauritius Mohun v. Jugnah \& ANOR of 2002 and in the judgment of the Intermediate Court Ramchurn Uma Parvati \& ORS v. Sahadeo Ashok \& ANOR of 2008.
} 


\subsection{Prohibition of Surrogacy Contracts and of Sale of Children in Mauritian Civil Law}

Surrogacy and sale of children entail not only Criminal law consequences but also Civil law consequences. Surrogacy may take two different forms (Courbe \& Gouttenoire, 2017, pp. 430-431; Garrigues, 2018, p. 702; Hess-Fallon \& Simon, 2014, p. 193; Neirnick, 2019, par. 48). On the one hand, surrogacy may be a gestational one, where an embryo has been conceived with the gametes (genetic material) of the couple who wants to get a baby or with the gametes of another donors and, after that, the embryo has been transferred into the surrogate mother's uterus. The latter is supposed to forfeit the baby after she gave birth to him/her and to hand over the child to the couple that is usually called "intended parents". On the other hand, the intended parents will sometimes have recourse to the medical technique known as surrogate mother: a surrogate mother will get inseminated artificially with the sperm of the intended father. In both above mentioned cases, the surrogate mother will abandon and surrender the child to the intended parents, after his/her birth. This second technique of surrogacy differs from the first one mentioned above in that the surrogate mother will not only carry the child but also conceive him/her with her genetic material. The surrogate mother gives her genetic material for the conception of the child who will be handed over to the intended parents. The surrogate mother is the biological mother of the baby (Mirkovic, 2008, par. 1 and 2).

Currently, surrogacy is a legal gap in Mauritian Civil Law (see: Law Reform Commission of Mauritius, n.d.). Thus, there are no specific rules on it neither in the Mauritian Civil Code nor in another enactment written in English. There are no specific rules which would explicitly declare contracts pertaining to this medical practice legal or prohibited by law in Mauritius.

As already explained, for historical reasons the Mauritian Civil Law is very much influenced by French Law (Agostini, 1992, pp. 21-22; Angelo, 1970, pp. 237-239; Bogdan, 1989, pp. 28-31; Domingue, 2002, p. 62; Venchard, 1982, p. 31). The judgments of the French "Cour de cassation" on civil law issues are considered as persuasive authority by Mauritian courts of justice and the legal reasoning of French Judges will often, but not always, ${ }^{57}$ be followed by their Mauritian counterparts. Thus, there is a strong probability that if and when a legal issue pertaining to the surrogacy contract is raised, a Mauritian Judge will follow the solution and spirit of the French Civil law which is the persuasive authority in Mauritius.

Article 16-7 of the French Civil Code formally prohibits the surrogacy (DekeuwerDefossez, Leroyer, \& Dionisi-Peyrusse, 2018, p. 583; Garrigues, 2018, p. 701; Le Gac-Pech, 2016, p. 486; Le Gidec \& Chabot, 2019, par. 35; Pichard, 2017, p. 1143 et seq.; Tourame, 2016, p. 275 et seq.), thus "any agreement relating to procreation or gestation on behalf of others is void". This rule is directly linked to the public interest, i.e. the directional public order (ordre public de direction) which is comprised of the fundamental values in French society, such as dignity of women (Courbe \& Jault-Seseke, 2019, p. 16). That is why the nullity of the surrogacy agreement is the absolute one (Hess-Fallon \& Simon, 2014, p. 193). Every interested person can invoke this nullity (Courbe \& Gouttenoire, 2017, p. 431) and the surrogacy contract cannot be confirmed by the gestational/surrogate mother and the intended parents. Even before Article 16-7 of the French Civil Code came into force, surrogacy agreements were strictly prohibited by the French "Cour de cassation". In the famous judgment of all chambers of the "Cour de cassation" given on $31^{\text {st }}$ May

\footnotetext{
57 Thus, the question of compensation of unmarried partner as indirect victim for the detriment suffered is differently solved in French Law and in Mauritian Law. See: Lingel-Roy M. J. E. M. \& Ors v The State of Mauritius \& Anor 2017 SCJ 411; Jugessur Mrs Shati \& ORS vs Bestel Joseph Christian Yann \& ANOR 2007 SCJ 106; Naikoo vs Société Héritiers Bhogun 1972 MR 66; Moutou vs Mauritius Government Railways 1933 MR 102.
} 
1991 (Courbe \& Gouttenoire, 2017, p. 430), we can read: "Considering articles 6 and 1128 of the Civil Code, together article 353 of the same Code; Whereas, the convention by which a woman undertakes, even free of charge, to conceive and carry a child and to abandon him after his birth is contrary both to the public order principle of the unavailability of the human body as well as to the principle of the unavailability of the state of persons (...)". The refusal by the French Civil Code and the "Cour de cassation" to validate contracts on the medical practice known as surrogacy is based on the idea that a woman and her body should not be used as a mere production tool. The capacity to carry a child is not something ordinary but one of the most intimate aspects of a women's existence. The pregnancy is not and cannot be considered as usual work (Courbe \& Gouttenoire, 2017, p. 430; Mirkovic, 2008, par. 8). Moreover, the idea to abandon a baby, a human being as a whole, to a couple who "ordered" him seems to be shocking (Garrigues, 2018, p. 702) and that is why the French "Cour de cassation", in its decision dated the $31^{\text {st }}$ May 1991 has cited Article 1128 of the Civil Code which prohibits the object of contract which is not in conformity with the law, public interest and good morals. It is certain that a baby (a human being) cannot be considered as an ordinary goods nor handed over to one party to a contract by another. The same reason accounts for the prohibition of sale of already born children.

Given the fact that the case law of the French "Cour de cassation" is the persuasive authority in Mauritius regarding Civil law cases, if, at some point, the legal issue of the validity of surrogacy agreements is raised before the Supreme Court of Mauritius, there is a strong probability that our Supreme Court will follow its French counterpart and will declare this type of agreement null and void, whether a consideration is given/promised to the surrogate mother or not. The same position should be held by the Mauritian Supreme Court in case of sale of already born child. Even though the principle of the unavailability of the human body is not explicitly provided for in the Mauritian Civil Code, there is no doubt that it can be inferred from the existing legislation in Mauritius (cf. Marais, 2018, pp. 173-174). Section 6 of the Mauritian Constitution prohibits slavery, ${ }^{58}$ and that means that no one in Mauritius can be sold for good consideration and deprived of his/her liberty. Human body as a whole is thus the material object that cannot be sold by contract (Penneau \& Terrier, 2019, par. 55), and this rule stems from Articles 1128 and 1598 of the Mauritian Civil Code. ${ }^{59}$ For the same reason, the contract on surrogacy should be illegal in Mauritius. This type of contract seems to be contrary to the public interest mentioned in Article 6 of the Mauritian Civil Code (Marais, 2018, p. 174), as well as to the dignity of the child who cannot be treated as an object of sale. Moreover, in Mauritius the dignity of a mother prohibits to treat her body as a simple tool of production.

\section{CHILD PROSTITUTION}

\subsection{Prohibition of Child Prostitution in the Children's Bill}

Section 17 (1) of the Bill prohibits child prostitution. Thus, "no person shall - (a) offer, obtain, procure or provide a child for prostitution; (b) cause, coerce, force, a child to participate in prostitution; (c) profit from, or otherwise exploit a child's participation in

\footnotetext{
58 "No person shall be held in slavery or servitude".

${ }^{59}$ Regarding other illegal objects from the point of view of the Mauritian Contract Law see: Section 6 of the Dangerous Drugs Act 2000; Section 3 of the Firearms Act 2006; Sections 4, 5 (1) et 17 of the Human Tissue (Removal, Preservation and Transplant) Act.
} 
prostitution; (d) have recourse to child prostitution". The non-respect of Section 17 (1) is a serious offence and is punished by penal servitude not exceeding 10 years and where the child victim is physically or mentally handicapped the penal servitude may go up to 20 years. The important definition of child prostitution is given in Section 17 (5) of the Bill: "the use of a child in sexual activities, for any form of consideration". Child prostitution entails also the Civil law consequences that have not been addressed in the Bill.

\subsection{Prohibition of Contracts Pertaining to Child Prostitution in Mauritian Civil Law}

A contract by which a child would promise sexual services to another person must be considered as null and void from the point of view of the Mauritian civil law. On the one hand, a contract made by a minor is usually considered as relatively null (frappé d'une nullité relative) for lack of capacity to make a contract. In Mauritian Civil Law the capacity to make a contract (capacité d'exercice) is normally acquired at the age of $18 .{ }^{60}$ A minor needs to be represented, i.e. he may only make contracts through his agent(s) designated by the Law and this agent/those agents is/are normally parent(s) of the minor. If the minor makes a contract personally, the latter will be deemed to be null and void for the lack of capacity. ${ }^{61}$ On the other hand, and this is even more important from the point of view of contracts pertaining to children prostitution, the object of a contractual obligation (objet de l'obligation contractuelle) which would consist of sexual services to another person for consideration is illegal, i.e. prohibited by the law. First of all, the above mentioned Section 17 of the Bill prohibits explicitly not only the contract made by a minor, provider of sexual services, but also the contract of agency pertaining to an act of sexual prostitution of a child. Second of all, these types of contract seem to be contrary to the public interest (ordre public) mentioned in Article 6 of the Mauritian Civil Code (Marais, 2018, p. 174). The public interest as a notion in Mauritian civil law is comprised of core values in the Mauritian society and it is certain that the need to protect a child as a very vulnerable person as well as the dignity of the child (the most intimate aspects of whom, i.e. his sexuality, may not be treated as an object of sale) are such core values. This is why a contract pertaining to prostitution of a child must also be considered prohibited by the Mauritian Civil law. The technical instruments which will allow a Judge to nullify a contract pertaining to child prostitution are Articles 1128, 1131 and 1133 of the Mauritian Civil Code. Article 1128 of the Mauritian Civil Code prohibits the object of contract which is not in conformity with the law, public interest and good morals. We have explained above why a contract aiming at child prostitution is contrary to the public interest in light of Article 1128 of the Code. Moreover, according to Article 1131 of the Mauritian Civil Code, "the obligation without cause, or on a false cause, or on an illicit cause, can have no effect". Article 1133 adds that "the cause is illegal when it is prohibited by law, when it is contrary to morality or public order". Articles 1131 and 1133 of the Mauritian Civil Code pertain to one of the fundamental elements of the Mauritian Contract law, i.e. the cause. According to the broadest definition of the cause [on the suppression of the notion of cause in the French Civil Code: Chénedé (2018, pp. 67-68); Tranchant, Egéa (2018, p. 42); Cabrillac (2018, p. 81 et seq.); Aubert, Collart-Dutilleuil (2017, p. 89 et seq.); Albiges, Dumont-Lefrand (2019, p. 71 et seq.); Mekki (2016, p. 494 et seq.); Terré et al.

\footnotetext{
${ }^{60}$ An exception is provided for by Articles 476 et seq. of the Mauritian Civil Code in case of emancipation of a minor by marriage. Thus, a minor 16 or 17 years old and married will acquire the capacity to make contracts, save the contracts which qualify as acts of commerce.

61 However, there is an exception to this rule and Article 390 of the Mauritian Civil Code derogate from the above mentioned prohibition in case of contracts which qualify as acts of everyday life (actes de la vie courante)
} 
(2019, p. 165 et seq.); Wicker (2015, p. 107 et seq.); Ansault (2014, p. 22 and 26); Ferrier (2015, p. 74); Houtcieff (2009, p. 198 et seq.)], the latter is the reason which explains why a party to a contract has decided to enter into it. The most logical application of this concept is the objective cause (cause objective), i.e. the cause of a contractual obligation. This cause is always the same in one given type of contract (Capitant, 1924, pp. 17-19, 43; Grimaldi, 2015, p. 814; Maury, 1920, pp. 32, 38; Mazeaud, 2013, p. 686 et seq.), such as sale agreement, exchange agreement, loan agreement, etc. For instance, in a sale agreement the cause of the obligation of the seller to convey the ownership of the sold item to the purchaser and to hand over that item to him consists of the payment of the purchase price. Vice versa, the cause of the obligation of the purchaser to pay the sale price consists of the obligation of the seller to convey the ownership of the sold item to the former and to hand over that item to him. Thus, given the fact that the object of the obligation of a child or his agent in a contract pertaining to child prostitution is illicit by virtue of Article 1128 of the Mauritian Civil Code, the cause of the obligation of the other party (the client) to pay the price will be illicit and the whole contract will be null and void. The nullity is an absolute one and every interested person, including the Attorney General's Office or the Ombudsperson for Children's Office, may bring an action before the court in order to nullify the contract.

\section{CONCLUSION}

In this article we have attempted to show that the Mauritian Children's Bill of 2019, which addresses many issues pertaining to child protection, such as best interest of a child, prohibition of discrimination of children, marriage of children, ill-treatment of children, surrogacy and sale of children and child prostitution, entails also civil law consequences that are not addressed in the Bill. We have highlighted the fact that the best interests of the child principle, which is set out in the Bill, is most of time well respected in the Mauritian Civil Code, but not always. We have drawn attention to the fact that the illegal discrimination of children and the ill-treatment of children, which are addressed in the Bill from the point of view of the Mauritian Criminal law, entail also Civil law consequences, i.e. the tort liability of the author of those acts. Forced marriage of children, whose Criminal law aspects are taken into account in the Bill, generate also Civil law consequences. On the one hand, every forced marriage in Mauritius is null and void from the point of view of the Mauritian Civil Code. On the other hand, child marriages are not necessarily null and void but strict conditions set out by the Mauritian Civil Code must be respected. Surrogacy, sale of children and child prostitution entail civil law consequences, i.e. Contract law consequences: contracts pertaining to surrogacy, sale of children and child prostitution are necessarily null and void as contrary to the public interest in Mauritius (ordre public).

\section{BIBLIOGRAPHY:}

Agostini, E. (1992). Heurs et malheurs du mariage religieux à l'lle Maurice. In G. Aubin (Ed.), Etudes offertes à Pierre Jobert. Liber Amicorum. (pp. 21-33). Bordeaux: Presses universitaires de Bordeaux.

Albiges, C., \& Dumont-Lefrand, M.-P. (2019). Droit des sûretés (7th Ed.). Paris: Dalloz. Angelo, A. H. (1970). Mauritius: The Basis of the Legal System. The Comparative and International Law Journal of Southern Africa, 3(2), 228-241. Retrieved 4 May 2020 from http://www.jstor.org/stable/23240787.

Ansault, J.-J. (2014). La Validité du contrat. Journal Des Sociétés, (118), 22-26. 
Aubert, J.-L., \& Collart-Dutilleul, F. (2017). Le contrat. Droit des obligations (5th Ed.). Paris: Dalloz.

Bogdan, M. (1989). The Law of Mauritius and Seychelles, A Study of Two Small Mixed Legal Systems. Lund: Wallin \& Dalholm Boktryckeri.

Boulanger, F. (2006). Applicabilité directe de la Convention de New York et intérêt supérieur de l'enfant. Recueil Dalloz, (8), 554-557.

Cabrillac, R. (2018). Droit des obligations (13th Ed.). Paris: Dalloz.

Capitant, H. (1924). De la cause des obligations. Paris: Librairie Dalloz.

Chénedé, F. (2018). Le nouveau droit des obligations et des contrats, consolidationsinnovations-perspectives (2nd Ed.). Paris: Dalloz.

Corpart I. (2015). Répertoire de droit civil, Emancipation. In Dalloz. Retrieved from https://www.dalloz.fr/.

Chouk, A. (2017). Administration légale pure et simple et administration sous contrôle judiciaire. Actualité Juridique Famille, 417 et seq.

Courbe, P., \& Gouttenoire, A. (2017). Droit de la famille (7th Ed.). Paris: Sirey.

Courbe, P., \& Jault-Seseke, F. (2019). Droit des personnes, de la famille et incapacités (10th Ed.). Paris: Dalloz.

Dekeuwer-Defossez, F., Leroyer, A.-M., \& Dionisi-Peyrusse, A. (2018). Remise en cause de l'interdiction de la GPA en France? Actualité Juridique Famille, (11), 583-586.

Domingue, P. R. (2002). The Historical Development of the Mixed Legal System of Mauritius during the French and British Colonial Periods. Research Journal, Law, Management and Social Sciences, 4, 61-93.

Egéa, V., \& Tranchant, L. (2018). Droit des obligations (23rd Ed.). Paris: Dalloz.

Fenouillet, D. (2019). Droit de la famille (4th Ed.). Paris: Dalloz.

Ferrier, N. (2015). Le Renforcement du rôle du juge dans la détermination et la révision du contenu du contrat. In R. Schulze, G. Wicker, G. Mäsch, \& D. Mazeaud (Eds.), La Réforme du droit des obligations en France, 5e journées franco-allemandes (pp. 73-94). Paris: Société de Législation Comparée.

Flour, J., Aubert, J.-L., \& Savaux, É. (2011). Droit civil. Les obligations. 2. Le fait juridique (14th Ed.). Paris: Sirey.

Garrigues, J. (2018). Droit de la famille (2nd Ed.). Paris: Dalloz.

Grimaldi, C. (2015). Les maux de la cause ne sont pas qu'une affaire de mots. Recueil Dalloz, (14), 814.

Hauser, J. (2015). Exclusion de l'administration légale dans une libéralité. Revue Trimestrielle de Droit Civil, 354.

Hess-Fallon, B., \& Simon, A.-M. (2014). Droit de la famille (9th Ed.). Paris: Sirey.

Hontebeyrie, A. (2016). Répertoire de droit civil, Prescription extinctive - Délais spéciaux. In Dalloz. Retrieved from https://www.dalloz.fr/.

Houtcieff, D. (2009). Le Contenu du Contrat. In F. Terré (Ed.), Pour une réforme du droit des contrats (p. 198 et seq.). Paris: Dalloz.

Jourdain, P. (2014). Les principes de la responsabilité civile (9th Ed.). Paris: Dalloz.

Lamarche, M., \& Lemouland, J.-J. (2014). Répertoire de droit civil, Mariage : conditions de formation. In Dalloz. Retrieved from https://www.dalloz.fr/.

Law Reform Commission, '(Organization/Institution)'. (n.d.). Background Paper, Reform of Codes. Retrieved 4 May 2020, from http://Irc.govmu. org/English/documents/Reports_and_Papers/34_reform-codes.pdf.

Law Reform Commission of Mauritius, '(Organization/Institution)'. (n.d.). Review Paper, Law on Surrogacy ("Maternité pour autrui"),. Retrieved 4 May 2020, from http://Irc.govmu.org/English/Reports/Documents/Review Paper Law on Surrogacy [Maternite pour autrui] (July 2013).pdf. 
Le Gac-Pech, S. (2016). Pour une indispensable légalisation des conventions de mère porteuse. Actualité Juridique Famille, (10), 486-490.

Le Gidec, R., \& Chabot, G. (2019). Rép. civ. Dalloz, Filiation : modes extrajudiciaires d'établissement. - Etablissement de la filiation par effet de la loi. In Dalloz. Retrieved from https://www.dalloz.fr/.

Lemouland, J.-J. (2020). Dalloz Action, Droit de la famille, Chapitre 111 - Conditions de fond du mariage. In Dalloz. Retrieved from https://www.dalloz.fr/.

Marais, A. (2018). Droit des personnes (3rd Ed.). Paris: Dalloz.

Marguénaud, J.-P. (2019). La neutralisation de l'intérêt prépondérant de l'enfant dans le processus décisionnel de déchéance de l'autorité parentale. Revue Trimestrielle de Droit Civil, 814.

Maury, J. (1920). Essai sur le rôle de la notion d'équivalence en droit civil français, tome premier: La notion d'équivalence en matière contractuelle. Paris: Jouve \& Cie, Editeurs.

Mazeaud, D. (2013). La Cause, une notion dans le vent.... Recueil Dalloz, (10), 686-690.

Mekki, M. (2016). L'Ordonnance n²016-131, du 10 février 2016 portant réforme du droit des contrats, du régime général et de la preuve des obligations. Recueil Dalloz, 494-505.

Mirkovic, A. (2008). A propos de la maternité pour autrui. Droit de La Famille, 9-13. Retrieved 4 May 2020 from https://www.ieb-eib.org/ancien-site/pdf/200505mere-porteuse-mirkovic.pdf.

Neirnick, C. (2019). Rép. civ. Dalloz, Enfance - Enfant, un être à protéger. In Dalloz. Retrieved from https://www.dalloz.fr/.

Penneau, J., \& Terrier, E. (2019). Rép. civ. Dalloz, Corps humain, Bioéthique. In Dalloz. Retrieved from https://www.dalloz.fr/.

Pichard, M. (2017). La commande d'enfant par son géniteur (est-elle une hypothèse de gestation pour le compte d'autrui ?). Recueil Dalloz, (20), 1143-1148.

Terré, F., Simler, P., Lequette, Y., \& Chenede, F. (2019). Droit civil, Les obligations (12th Ed.). Paris: Dalloz.

Tourame, P. (2016). Quelle liberté pour la mère porteuse. Les Cahiers de La Justice, (2), 275-288.

Valentine, P. V. (Ed.). (2012). Mixed Jurisdictions Worldwide, The Third Legal Family (2nd Ed.). Cambridge: Cambridge University Press.

Venchard, L.-E. (1982). L'application du droit mixte à l'Ile Maurice. Mauritius Law Review, (4), 30-44.

Wicker, G. (2015). La Suppression de la cause et les solutions alternatives. In R. Schulze, G. Wicker, G. Mäsch, \& D. Mazeaud (Eds.), La Réforme du droit des obligations en France, 5e journées franco-allemandes (pp. 107-138). Paris: Société de Législation Comparée. 
